\title{
Exploring EFL Writing Assessment in an Egyptian University Context: Teachers and Students' Perspectives
}

\author{
Abdelhamid Ahmed \\ Core Curriculum Program, Qatar University, Doha, Qatar; \\ Curriculum \& Instruction Dept., Faculty of Education, Helwan University, Egypt \\ Salah Troudi \\ Graduate School of Education, University of Exeter, UK
}

\begin{abstract}
The study identified the assessment practices used in an Egyptian EFL writing course at university and explored teachers and students' perspectives of these assessment practices. The focus was on the assessment practices to inform and propose appropriate implications. This study is informed by social constructivism where knowledge is constructed socially through the perceptions of different participants. Eight students and eight EFL writing teachers were interviewed, and three EFL writing classes were observed. Findings revealed that writing assessment is important to both teachers and students. Diagnosing students' writing was done rarely and superficially, using a non-standardised assessment. Reported formative assessment practices include attendance, homework, samples of students' writing, class participation, assignments, and oral presentation. Stereotypical final exams were reported as the only summative assessment practice. Finally, the assessment criteria and the analytical scoring method were not communicated to students. Observed EFL writing classes mostly confirmed students' perspectives about the reported practices. Implications and suggestions are provided.
\end{abstract}

Index Terms-assessment practices, EFL writing assessment, Egypt, students' perspectives, teachers' perspectives

\section{INTRODUCTION}

Research highlighted the need to assess students' skills in English as a Foreign Language (EFL) writing in more informative, accurate and effective ways (Weigle, 2012). Assessing writing is important not only for teachers and students but also for programme administrators and stakeholders in language learning (Jones, 2002; Cumming, 2004). Assessment is closely connected to the learning process as changing methods of assessment will contribute to a change in students' learning (Brown, 1997). Assessment helps students identify their points of weaknesses and strengths in writing to take the appropriate remedial action (Hyland, 2004, p. 213). For students, assessment defines the curriculum that they study (Ramsden, 1992). In other words, assessment informs students about their mastery level of specific skills and their achievement of the Student Learning Outcomes (SLOs). In reference to teachers, they view writing assessment as a continuous process that involves both teachers and students (Crusan, 2010).

The authors were motivated to explore perspectives of both Egyptian EFL writing teachers and their students about writing assessment in Egypt, as it is actually practiced, based on three compelling reasons: the exam-oriented culture, lack of attention to the interrelationship between writing instruction and assessment, and filing in the gap in the literature and contributing to the field of EFL/L2 writing by broadening our understanding of the writing assessment practices in different contexts (Cumming, 2004). First, the educational system in Egypt operates as an exam-oriented culture and one that favours summative assessments of student learning (Hargreaves, 2001; Hartmann, 2008; Ahmed, 2010; Gebril \& Brown, 2014; Ahmed, 2016, Ahmed, 2018). Second, writing instruction and assessment are not highly prioritized in Egypt, so those teaching writing may well lack sufficient training and might be assessing student writing without any focus on formative assessment of writing, (Ahmed, 2010b, p. 214; Crusana, Plakansb, Gebril, 2016) that is highly established in the EFL/L2 writing field. Therefore, the authors wanted to find out what happens when Egyptian EFL teachers assess students' writing. In addition, it could be argued that this type of situation is common in other EFL/L2 contexts such as Japan (Hyde, 2002), China (Reichelt, 2009), Tunisia (Athimni, 2018), Egypt (Ahmed, 2018; Sadek, 2018; Shabana, 2018), Morocco (Abouabdelkader, 2018), Qatar (Weber, 2018), Yemen (Ghalib, 2018) and so there is value to the field in examining it.

It is important to understand writing teachers and their students' perspectives of teaching and assessment of L2 writing. Despite the challenge to investigate teachers' views about assessment practices (Baird, 2014), they are important for two reasons (Matsuda, Saenkhum and Accardi, 2013). First, it helps to understand the context within which L2 writing is taught and assessed. Second, it helps identify L2 writing teachers' views and concerns and informs 
their professional development needs. Students' perspectives about L2 writing assessment are also important as they help teachers understand students' reaction to feedback (Zhang, 1995; Cumming \& So, 1996; Nelson \& Carson, 1998; Ferris \& Roberts, 2001). Therefore, the current study explores the assessment practices in an EFL writing course at the university level in Egypt from the perspectives of both teachers and their students. This will help understand the Egyptian university context in which EFL writing is taught and assessed as well as giving an opportunity to Egyptian university teachers and students to voice their concerns about EFL writing assessment.

\section{FORMS OF WRITING ASSESSMENT IN EFL/L2}

This literature review discusses five main strands relating to writing assessment. The first strand attempts to shed light on the purposes of assessment in Egypt. The second strand seeks to define diagnostic assessment focusing on its purposes and significance to EFL writing. The third strand reviews formative assessment, with a particular reference to self-assessment, and peer assessment. The fourth strand examines summative assessment, with a particular reference to exams and rating criteria. The last strand highlights some factors that account for teachers' assessment practices. This section concludes with the current study's potential contribution to the literature on writing assessment in an underrepresented EFL context.

\section{A. Assessment in Egypt}

Research about assessment in Egypt revealed that purpose of assessment has shifted to better learning (Hargreaves, 2001; Gebril \& Brown, 2014). Hargreaves (2001), in her review of assessment in Egypt, highlighted that the government aimed to improve assessment to improve the educational system and individual learning. However, the use of formal written examinations based on memorisation and rote learning drifted away from any individual learning. In addition, Gebril \& Brown (2014) identified Egyptian teachers' beliefs about three assessment purposes: improvement, school accountability and irrelevance. Moreover, research revealed that feedback practices in Egypt in EFL writing courses are rare and the assessment practices are traditional (Ahmed, 2010b, pp. 214-219).

\section{B. Diagnostic Assessment}

Research suggests that diagnostic assessment guides learning, identifies students' strength and weaknesses, improves instruction and evaluates students' progress and helps teachers design teaching materials that help students develop their skills (Hyland, 2007; Jang, 2009). For example, Ferris \& Roberts (2001) asked 72 university ESL students to take a diagnostic test to identify their level of ESL writing before their experiment. Similarly, Storch (2009) used a universitydesigned diagnostic test with 25 international students to identify their need for extra language support and recommend an appropriate intervention. However, diagnostic assessment does not provide students with diagnostic feedback about their points of strength and weaknesses in the assessed skills (Nichols, 1994; Snow \& Lohman, 1989; Alderson, 2005; Gorin, 2007). Therefore, part of this study is to explore the perspectives of Egyptian EFL writing teachers and their students on the current diagnostic assessment practices.

\section{Formative Assessment}

On the other hand, formative assessment is specifically intended to generate feedback on performance to improve and accelerate learning (Sadler, 1998). In addition, Hyland (2004, p.213) describes formative assessment as "any assessment designed to identify the learner's strengths and weaknesses to effect remedial action". Lee (2011) pinpointed that formative L2 writing assessment can be used to enhance teaching and learning provided that teachers: (1) believe in the need for change, (2) persist to innovate and improve their practice, and (3) work within a supportive system, (4) collaborate, reflect critically and engage in continuing professional development (ibid). In line with this, Graham, Hebert \& Harris (2015) examined the impact of formative writing assessment on enhancing students' written performance and found out that feedback received on students' writing from teachers, peers, self and computers has proved effective in enhancing students' writing performance with effect size of $(0.87,0.58,0.62$ and 0.38$)$ respectively.

Self-assessment as a formative assessment practice in writing courses is concerned with judging, evaluating and considering the qualities of one's own academic work or abilities (Kasanen \& Räty, 2002). Research reported that experienced teachers who used Student Self-Assessment (SSA) in the writing classroom viewed it as a positive experience; whereas, novice teachers viewed it as ineffective. For example, Panadero, Brown \& Courtney (2014) explored 944 Spanish teachers' beliefs about SSA and results indicated that $90 \%$ of teachers reported positive experiences about it. On the other hand, Belachew, Getinet \& Gashaye (2015) investigated the perceptions and practices of 10 EFL teachers and 50 English majoring students towards self-assessment. Findings revealed that most teachers did not have any experience of using self-assessment in writing classrooms and felt that students did not have the potential to make an honest assessment of written tasks. Most students who overrated their written performances decreased from $56 \%$ in the first phase to $44 \%$ during the last session. Few other students who genuinely rated their writing increased from $30 \%$ in the first phase to $40 \%$ in the fourth phase.

Peer assessment, as another form of formative assessment, is believed to be beneficial for both students and assessors (Brown, Rust \& Gibbs, 1994; Zariski, 1996; Race, 1998; Bostock 2000). Irrespective of the benefits and challenges of peer assessment, inconsistent findings were reported about students' perspectives (Saito \& Fujita, 2004; Matsuno, 2009; 
Wang, 2014). For instance, Saito \& Fujita (2004) conducted a study to measure students' self, peer and teachers' rating of the same essays. Forty-seven Japanese college students in an English writing course wrote two essays. Two teachers, three peers and the writers themselves gave feedback on each essay. Results revealed that peer and teacher ratings correlated considerably and students had favourably liked peer rating. In another study, Matsuno (2009) investigated how self- and peer-assessments work compared with teacher assessments in university writing. Findings indicated that many self-raters assessed their writing lower than expected, which was particularly true for high-achieving students. Peer-raters rated high-achieving writers lower and low-achieving writers higher. Self, peer and teacher-raters assessed Grammar severely and Spelling mildly. Moreover, teacher-raters assessed Spelling, Format, and Punctuation differently from the other criteria. Moreover, peer assessment was somewhat peculiar and of limited benefit as part of the formal assessment. Wang (2014) explored students' perspectives of peer feedback on EFL writing, the factors which affected its usefulness and students' views about using a rubric while giving peer-feedback. Findings showed that five factors affected the usefulness of peer feedback: knowledge of writing topics; attitudes towards the practice of peer feedback; time constraints; limited proficiency of English; problems with interpersonal relationships.

\section{Summative Assessment}

Summative assessment is the third form of assessment discussed here. Hyland defines it (2004, p.213) as "any assessment concerned with summing up how much a student has learned at the end of a course." To this end, many writing teachers use tests to measure students' achievement in writing (Assad, 1985; He \& Shi, 2008). For instance, a study investigated 16 EFL international students' perceptions and experiences of two English writing tests: Test of Written English (TWE) and the essay task in English Language Proficiency Index (LPI) (He \& Shi, 2008). Findings showed that memorisation of writing samples helped students pass TWE; however, the same participants failed LPI due to lack of skills needed to construct texts. Students did not fully understand the expectation of the LPI task and their complaints about the complexity of writing prompts raised questions about the test validity.

\section{E. Factors Impacting Assessment}

Research showed that some factors account for teachers' assessment practices: teachers' specialisation, assessment literacy, lack of teaching qualification, teacher-student power relations, high-density classrooms and marking load and some socio-cultural issues. First, research indicated that teachers' specialisation affects effective teaching and learning (Hailu \& Rustaman, 2012). For example, students who studied courses with specialised teachers scored higher than those who did with unspecialized teachers (Winnaar, Blignaut \& Frempong, 2011). Second, assessment literacy influences teachers' knowledge of the skills, purpose and mechanism of assessment. Therefore, assessment-literate teachers become aware of any negative consequences (Stiggins, 1995).

Another important factor is teachers' lack of teaching qualification. In Egypt, along with other similar EFL contexts, many EFL writing teachers lack knowledge of learning, teaching and assessment due to not obtaining a teaching qualification/training in assessment of EFL writing (Yang, 2007, Mertler, 2009; Seliem \& Ahmed, 2009). This leads to difficulty in making solid assessment decisions and conducting competent assessment of students' writing (Mertler, 2009).

The issue of teacher-student power relation is believed to affect the teaching and assessment practices. Teacherstudent interaction can either promote power relations or support collaborative relations Cummins (2009). Research within the Egyptian context pointed out that teacher-student interaction appears to enhance strong power relations (Ahmed, 2010a, p.509) and restricts students' ability to argue or negotiate meaning or interrogate teachers' authority (Ahmed, 2016).

Teaching in high-density classrooms is another issue that does not nurture a favourable learning environment (Faour, 2012). Research revealed that large classes require teachers to exert extra efforts and allocate much time to read students' work and assess their writing performance (Billington, 1997; Race, 1998; Davies, 2000). In the Egyptian context, large classes (i.e. 100-200 students) reduce the quality of teaching, learning and assessment of EFL writing (Ahmed, 2016).

Teaching/marking load is another hindering factor related to large classrooms. Research showed that teaching load limits teachers' skills in planning and applying productive pedagogy (Gore, Griffiths, \& Ladwig, 2004). It is claimed that workload/marking load could cause stress for university teachers (Boyd, \& Wylie, 1994; Yang, 2007).

The socio-cultural context affects the educational system in Egypt where more emphasis is given to writing to pass exams which reduces EFL writing to a mere grade. In addition, stereotyped EFL writing exams at the university level in Egypt require much attention as they encourage memorisation and discourage learning how to write. (Ahmed, 2016; Ahmed \& Myhill, 2016). In Egypt, research showed that the teaching of EFL writing is characterised by traditional topics of writing, prohibited topics of writing, formulaic expressions, rote learning, competitive learning, lack of reading and exam culture (Ahmed \& Myhill, 2016).

The above literature indicates that teachers and their students' perspectives about the different assessment practices converged in many respects. First, both teachers and their students believed that assessment closely connects to the teaching and learning processes (Brown, 1997); precisely defines the curriculum (Ramsden, 1997), and identifies students' points of weaknesses and strength in writing and proposes appropriate intervention (Hyland, 2004). Second, teachers and students believe that the benefits of self-assessment outweigh its disadvantages. Despite being reported as 
exhausting and time-consuming (Mires, Ben-David, Preece, \& Smith, 2001), self-assessment was revealed to improve students' self-regulation (Klenowski, 1995; Ramdass \& Zimmerman, 2008; Brown \& Harris, 2013; Panadero \& Romero, 2014); enhance achievement (Panadero \& Romero, 2014); improve students' performance in final exams (McDonald and Boud, 2003); identify and correct more errors when enhanced with teacher feedback (Taras (2001); criticise students' own work in a more structured way (Orsmond, Merry \& Reiling, 1997). In addition, peer assessment yielded more benefits than encountered challenges such as developing students' sense of responsibility, ownership and evaluation skills and a deeper approach to learning (Brown, Rust \& Gibbs, 1994; Zariski, 1996; Race, 1998; Bostock 2000). However, more guidelines and support to teachers about how to implement it in class is needed (Yuen, 1998). Some factors were reported to influence teacher assessment practices such as perceived competency, teachers' beliefs, assessment education, knowledge of language learning and teaching, contextual milieu and socio-political factors (Lee, 2003; Yang, 2007; and Troudi, Coombe, and Al-Hamly, 2009).

The current study seeks to contribute to the assessment of EFL writing in two ways. First, it focuses on the Egyptian university context, a population that has not received the due attention in the literature. To the best of the researchers' knowledge, no previous studies in the field of EFL writing in general and in the Egyptian context, in particular, have addressed assessment practices from both teachers and their students' perspectives using interviews and observation. Second, it compares teachers and students' views about EFL writing assessment practices to (1) shed light on some of the beliefs underlying teachers' assessment practices; (2) provide a greater understanding of how these assessment practices address students' EFL writing needs; and (3) offer research-based evidence about the professional development needs of EFL writing teachers.

The above-reviewed literature informed and framed the current study in three ways. First, it helped the researchers develop the research questions to explore the gap between teachers and students' views about EFL writing assessment. Second, it helped the researchers select and develop the semi-structured interviews and the semi-structured observation. Finally, it helped the researchers have a dialogic relation between the reviewed literature and the discussion of the findings.

\section{Research Questions}

The following research questions guided the current study:

1. How do Egyptian EFL teachers of writing view their assessment practices in an Egyptian university context?

2. What do Egyptian undergraduate students think of the assessment practices employed by their EFL teachers of writing?

\section{Methodology}

This study is situated within the interpretive qualitative research approach which aims to understand the context within which participants act, the process within which actions happen to tell us from an insider's view why things happened in the way they did (Maxwell, 1996, Denzin \& Lincoln, 2000). Cumming (2004) highlighted that the different forms of qualitative research would help gain insights into language assessment issues through accommodating the interests of practitioners, educators and researchers who explore language assessment issues. Therefore, the current study adopts a case study methodology where two data collection methods are used (i.e. semi-structured interviews and semi-structured observations).

Social constructivism informs this study's theoretical framework where knowledge is constructed socially through the perspectives of different participants (Burr, 1995; Andrews, 2012, p.39). As a learning theory, social constructivism "emphasises the role of culture and context in developing personal and shared interpretations and understanding of reality" (Pritchard \& Woollard, 2010, p.9). The Egyptian educational and cultural contexts play a role in reducing English writing for exam purposes. The educational context seems to be competitive, reliant on spoon-feeding and exam-oriented; while the Egyptian socio-cultural context restricts freedom of expression, lacks opportunities to argue about views, encourages the use of traditional and non-controversial writing topics, and rote learning (Ahmed \& Myhill, 2016).

\section{A. Participants}

Eight English majors (see table 1) and eight EFL writing teachers (see table 2) voluntarily took part in the current study at a Faculty of Education in Egypt. The teachers and their students are Egyptian and are selected based on the accessibility criterion (Silverman, 2001) at the English Department, Faculty of Education in an Egyptian public university. 
TABLE (1)

\begin{tabular}{|l|l|l|l|l|l|}
\hline \multicolumn{4}{|c}{} & \multicolumn{3}{|c|}{ DEMOGRAPHIC DATA OF EGYPTIAN ENGLISH MAJORS } \\
\hline No. & Pseudonym & Gender & Year of Study & Age & Department \\
\hline 1. & Khalid & Male & First Year & 18 & English Dept., Faculty of Education. \\
\hline 2. & Rami & Male & Sophomore & 19 & English Dept., Faculty of Education. \\
\hline 3. & Mahmoud & Male & Junior & 20 & English Dept., Faculty of Education. \\
\hline 4. & Banan & Female & First Year & 18 & English Dept., Faculty of Education. \\
\hline 5. & Azza & Female & Sophomore & 19 & English Dept., Faculty of Education. \\
\hline 6. & Amal & Female & Senior & 21 & English Dept., Faculty of Education. \\
\hline 7. & Khadiga & Female & Senior & 21 & English Dept., Faculty of Education. \\
\hline 8. & Asmaa & Female & Junior & 20 & English Dept., Faculty of Education. \\
\hline
\end{tabular}

Table (1) shows that eight Egyptian English majors participated in the current study: three males and five females. Participants' year of study varied across the four-year teacher education programme. They are full-time students at the English Department, Faculty of Education in Egypt, whose age ranges from 18 - 21 years old.

TABLE (2)

DEMOGRAPHIC DATA OF EGYPTIAN EFL WRITING TEACHERS

\begin{tabular}{|l|l|l|l|l|l|}
\hline No. & Pseudonym & Gender & Teaching Experience & Qualification & Academic Affiliation \\
\hline 1. & Mostafa & Male & 3 yrs. & M.A. in English Literature & English Dept., Faculty of Arts. \\
\hline 2. & Alaa & Male & 5 yrs. & PhD in English Linguistics & English Dept., Faculty of Arts. \\
\hline 3. & Mohammed & Male & 7 yrs. & PhD in English Literature & English Dept., Faculty of Arts. \\
\hline 4. & Atiyat & Female & 10 yrs. & M.A. in English Literature & English Dept., Faculty of Arts. \\
\hline 5. & Lara & Female & 4 yrs. & PhD in English Literature & English Dept., Faculty of Arts. \\
\hline 6. & Reem & Female & 5 yrs. & PhD in English Linguistics & English Dept., Faculty of Arts. \\
\hline 7. & Lamiaa & Female & 9 yrs. & PhD in English Linguistics & English Dept., Faculty of Arts. \\
\hline 8. & Esraa & Female & 6 yrs. & & \\
\hline
\end{tabular}

Table (2) shows that eight EFL writing teachers participated in the current study: three males and five females. Three teachers are holders of M.A. degrees while the other five are holders of $\mathrm{PhD}$ degrees in English Literature/Linguistics. They work as full-time teachers at the English Department, in a Faculty of Arts in Egypt, and are seconded to teach essay writing at the Faculty of Education. Male writing teachers have 3-7 years of teaching experience; while, the female ones have 4-10 years of teaching experience.

Most Egyptian students, who join the English department at Faculty of Education, are holders of General Certificate of Education (GCE) with a high score. In reference to the admission criteria at Faculty of Education, students must obtain no less than $85 \%$ in the GCE, as well as a score of $85 \%$ in the final English exam.

The essay writing course is compulsory for all undergraduate students in the English Department. It does not have a unified syllabus with specific textbooks; therefore, it differs from one teacher to another. The following three different books are used among different teachers of writing: "Weaving It Together: Connecting Reading and Writing", TOEFL Preparation, Introduction to Academic Writing. Two assessment methods are used: formative (20\%) and summative assessment (80\%).

\section{B. Data Collection and Analysis}

Two data collection methods are used in the current study: semi-structured interviews with eight English majors and eight EFL writing teachers, and a semi-structured observation of three essay writing classes. Using semi-structured observation along with the semi-structured interviews complemented and triangulated data collection and analysis.

\section{Semi-Structured interviews}

The researchers designed two semi-structured interview schedules for teachers and students (nine questions each). To check the validity of the semi-structured interview schedules, a trial run was conducted (Dornyei, 2007) with two writing teachers and three English majors. Some modifications were made based on their feedback to produce the final versions of the semi-structured interview schedules as shown in appendices $(1 \& 2)$. Then, semi-structured interview sessions were arranged with eight EFL writing teachers and eight English majors. Teachers' interviews lasted for 20 30 minutes; whereas, students' interviews lasted for 15-22 minutes. These interviews were transcribed and returned to interviewees for validation. All interview transcripts were checked for respondent validation (Randor, 2002) as they agreed to the transcripts.

Analysis of interview transcripts was guided by data reduction, data display and conclusion drawing/verification (Miles and Huberman, 1994; Holliday, 2002; Ritchie \& Lewis, 2003; Bryman, 2008). Data was prepared for analysis using three excel sheets as informed by the interview schedules and the observation sheet: one for students' responses to the interview questions, another for teachers' responses and the third one for observational data. All responses to each interview question were grouped into categories and sub-categories as guided by the interview questions and observation constructs. After that, data extracted from the interviews and the observation was analysed to come up with thematic charts, themes and sub-themes, along with their quotes and codes.

\section{Semi-Structured Classroom Observation}

Semi-structured observation is one of the three observation types to which Cohen, Manion \& Morrison (2007) referred. It captures what actually takes place in situ (Ruane, 2005). Guided by the research questions along with the 
preliminary analysis of the interviews, a semi-structured classroom observation was designed focusing on identifying and exploring diagnostic, formative and summative assessments, and assessment criteria (See appendix 3). Permission was granted from three EFL writing teachers and their students to observe their classes. Nine lectures were observed, each of which lasted for ninety minutes. Bryman (2008) suggested the use of two observers and cross-checking observation notes enhances investigator triangulation and enriches the validity of the observation as a research instrument, resulting in a more credible data. The two observers cross-checked their descriptive notes and ensured a consensus was reached on any difference in views.

Field notes of both observers were categorised and coded under the following themes: diagnostic assessment, formative assessment, summative assessment, and assessment criteria. These themes were matched against the data extracted from the semi-structured interviews. Thus, to answer the research questions, researchers combined and presented data from the semi-structured interviews and semi-structured observation to form an argument, where appropriate.

\section{Ethical Issues}

BERA (2004) ethical considerations guide the current study. First, researchers informed the participants about the purpose of the study and asked them to sign an informed consent form before their voluntary participation. Second, researchers ensured participants' anonymity, confidentiality and privacy by using pseudonyms and keeping their information in a secure place. Third, researchers told participants that they have the right to withdraw from the study for any reason and at any time. Finally, researchers returned the interview transcripts to participants to do member checking to ensure trustworthiness in qualitative research (Given, 2008).

\section{FINDINGS \& DisCUSSION}

Data analysis revealed that Egyptian EFL writing teachers and their students' perspectives of the assessment practices evolved around the following themes: the importance of writing assessment, diagnostic assessment, formative assessment, summative assessment and assessment criteria.

\section{A. The Importance of Writing Assessment}

Analysis of students and teachers' interview data showed that assessing writing is important for some reasons: teacher objective assessment of student writing, analysis of students' weaknesses and strengths in writing, and design of activities that enhance the under-developed writing skills. Five teachers highlighted the importance of assessing students' EFL writing. Mostafa shows us a sample example as follows:

Assessing students' writing helps me to give them a fair score. It also helps me to reveal students' points of strengths and weakness in EFL writing and design some activities tailored to develop these under-developed skills.

Six students reported that assessing writing is useful. Banan explains as follows:

At university, English writing professor can adequately assess my writing level and pinpoint my weak points and areas for improvement. Writing professors focus on content, ideas, organisation, and the genre of writing such as descriptive or narrative. This is really helpful.

\section{B. Diagnostic Assessment Practices}

Analysis of teachers and students' interviews as well as observational data revealed that Egyptian writing teachers diagnose their students' writing skills based on their personal experience as students. For example, Alaa justified his diagnosis of students' writing skills as follows:

In Week (1), I ask students to write one or two paragraphs on a certain topic, and I do correct these paragraphs attentively to identify students' problems in writing. However, I do not have time due to large class sizes that exceed 100 students and the many classes I teach.

In addition, Atiyat related the purpose of diagnostic assessment to planning her writing syllabus thus:

At the beginning of the course, I give students an essay, which is full of drastic mistakes, to correct these mistakes and I am surprised that they cannot find any mistakes. This indirectly gives me an idea about the skills I should focus on when I develop my writing syllabus.

With regard to students' views about diagnostic assessment, six students said that they have never had their writing skills diagnosed. For example, Khalid said:

The teacher, in the first week, always asks us to buy a particular book from the bookshop and prepare the first few pages. The teacher never asks us to write about any topics.

On the other hand, Azza described what her teacher asked them to do in the first class as follows:

Our writing teacher asked us to write a paragraph on one of three topics. However, we did not get any oral or written comments from the teacher or even had our marked papers back.

Observation data showed that teachers diagnosed students' writing superficially thus:

The teacher asked students to write an essay on a topic of their choice. He did not inform students of the purpose of this exercise. The teacher said that he would mark only a sample of the whole class and discusses comments as a whole in the next few weeks. 
The findings reveal that teachers diagnose students' writing; however, these assessments seem to be not standardised or unified. Moreover, teachers do not have the time to mark students' writing due to their teaching overload and the large classes. Research showed that teaching load could hinder teachers' skills to plan and apply productive pedagogy (Gore, Griffiths, \& Ladwig, 2004). Moreover, teaching/marking load was also shown to cause most stress among occupational groups at the university level (Boyd, \& Wylie, 1994; Yang, 2007). This is particularly true of the EFL writing teachers in the current study as more than 100 students in class denotes a marking load, especially in EFL writing courses.

Large classes constitute a big problem when it comes to assessment, as it requires teachers to exert great efforts and assign lots of time to assess students' performance in writing (Billington, 1997; Race, 1998; Davies, 2000; Faour, 2012). This leads students to compete for fewer resources and receive fewer tutorial support sessions with their teachers to get feedback on their writing. Large classes in Egypt are also evident as it influences the quality of teaching and learning of EFL writing (Ahmed, 2016).

\section{Formative Assessment Practices}

Analysis of interview and observation data showed teachers and students' concerns about the following formative assessment practices: attendance, homework, samples of students' writing, class participation, assignments, and oral presentation. For example, five teachers reported collecting samples of students' writing and marking them at home. Alaa, for example, stated:

I collect samples of students' essays to mark and return them to my students. Due to my teaching load, I cannot mark 120 pieces of writing in each class.

In addition, Lara commented on her lack of training and resources about the assessment of students' writing thus:

Honestly, I need to be trained in how to assess students' writing. Even when I try to visit the university library to access resources, I only find very old resources that go back to the 1980s.

However, other teachers rely on participation, assignments, and discussion in their formative assessment. As an example, Reem justifies her use of these practices as follows:

Students' class participation, assignments, and discussion are the basis upon which I assess students' writing. I actually resort to class participation to identify those who have prepared the lesson, did the homework, and give them grades to encourage them to do their homework regularly.

Research highlighted that assessment-literate teachers know what skills to assess, why to assess these skills and how to assess them effectively (Stiggins, 1995). EFL writing teachers in the current study, like others in similar contexts, lack knowledge of EFL teaching, learning and assessment as they do not have a teaching qualification or did not receive training on assessing EFL writing (Yang, 2007, Mertler, 2009; Troudi, Coombe \& Al-Hamly, 2009). We can argue that this applies to the Egyptian context under investigation where teachers do not have a teaching qualification and are therefore unable to conduct a sound assessment of EFL writing (Mertler, 2009).

In the current study, EFL writing teachers are not specialised in teaching EFL writing. Research showed that students of specialised teachers scored higher than did those of unspecialized teachers (Winnaar, Blignaut, \& Frempong, 2011). Also, the courses given by unspecialized teachers had little impact on the quality and effectiveness of teaching and learning (Hailu \& Rustaman, 2012). We can argue that this is true as EFL writing teachers in the current study are not specialised in teaching EFL writing.

Lack of training, time and incentives constitute barriers to pedagogical change and teachers' assessment (Henderson, Beach \& Finkelstein, 2011; Yang, 2007). The effects of peer assessment training on teachers' assessment performance helped them define performance criteria, give feedback and write assessment reports. (Sluijsmans, Brand-Gruwel, \& Van Merriënboer, 2002). Research showed that inadequately trained Egyptian EFL teachers negatively influence the quality of teaching EFL in Egypt (Fareh, 2010). Moreover, Egyptian teachers lacked time to read students' written essays and give them feedback (Seleim \& Ahmed, 2009). Therefore, Brownell \& Tanner (2012) call for training, time and incentives to improve faculty teaching practices. We can argue that this applies to the Egyptian context under investigation where EFL writing teachers need to be trained on the latest trends in EFL writing assessment (Ahmed, 2010b, p. 214; Ahmed, 2016).

With regard to students' views about formative assessment, three students highlighted that their teachers' assessment is inappropriate as it does not measure the different writing skills, but instead focus on decontextualised vocabulary. For example, Amal said:

The teacher gave us a list of words to look up in the dictionary. This is the only assessment we underwent during the course.

Asmaa criticised her teacher for not giving feedback as follows:

The teacher asked us to write a descriptive essay, and he did not provide any feedback on our essays.

In addition, Rami commented that the teacher does not seem to be able to assess the different levels of students, as she does not use an assessment rubric:

My EFL writing teacher does not specify any criteria to assess my homework or assignment. I do not know how my writing is assessed.

Observational data analysis revealed in-class writing as another assessment practice that EFL teachers use. An example of this is shown below: 
After teaching students how to develop a topic sentence, he asked them to develop one of five topic sentences into a complete paragraph. In the next class, the teacher returned the papers among students with no marks, but some underlining of problematic sentences in red.

With regard to the homework and class discussion as other assessment practices, observational data describes how the teacher dealt with this assessment:

The teacher assigned a task worth $2 \%$ of the course. In the next class, she randomly selected some tasks to be checked orally. In the next class, she wrote down in her notebook the names of students who completed the homework and discussed it orally with her.

In reference to students of the current study, it is important to understand why they hold these views about assessment practices in the EFL writing class in Egypt. First, as (Ahmed \& Myhill, 2016) highlighted, the Egyptian educational system stresses writing to pass exams which reduces EFL writing to a mere product and a grade. In addition, it was reported that teachers at a specific Faculty of Education do not use clear assessment criteria (ibid). Second, large class sizes of over 100 students made it difficult for students to learn how to write and for teachers to assess them accurately. Students started to compete for fewer resources and fewer individual tutorial sessions with their writing teachers to receive teachers' feedback (Ahmed, 2016). In addition, students' previous experiences with the assessment of writing with other teachers at the university made them very keen on getting the highest marks possible. Students held negative views towards assessment since their assessment experiences have been primarily high-stakes and examoriented. They might have obtained a low grade in a previous writing course that made them only think of the exam and the final mark irrespective of learning experiences. Another issue that justifies their views might be employability after graduation, as the Ministry of Education in Egypt does not appoint teachers whose overall evaluation is less than "Merit" in their B.A. degree. This intensifies the competition among students to survive in an environment fenced with limited opportunities to succeed and work.

\section{Summative Assessment Practices}

All teachers reported using the final exam as the only summative method of assessing students' EFL writing skills. Concerning the components of the final exam, it differed from one teacher to another. For some teachers, it only meant assessing students by writing an essay on a certain topic and answering some reading comprehension questions. A sample example of this is shown in Lamiaa' extract below:

Because I always teach reading and writing within the same course, I get students a reading comprehension text of medium difficulty level, but a bit lengthy. I ask some questions reading comprehension questions. The second part of my exam asks students to write an essay on one of three topics and punctuate a paragraph that lacks punctuation marks.

For other teachers, the final exam means testing students' essay writing skills covered in the syllabus. Esraa's words below shed light on her lack of a teaching qualification and experience in designing exams, as is the case with many other teachers, as follows:

I am a PhD holder in Linguistics, and I do not have a teaching qualification, like most writing teachers. Also, I do not have enough knowledge and experience to design writing exams, but I just look at previous exams designed by other colleagues and try to design a similar one. Usually, the exam consists of an essay, to which students should write an outline, an editing question, a lexical question and an introduction/ a conclusion to write for a written essay.

All students confirmed that the final exam was the only summative assessment practice used by their teachers. Students believe that final exams are stereotyped and repetitive. Banan illustrates this point:

The final exam is the only assessment worth $80 \%$ of the course. The exam is the same type of questions every year. It consists of two parts: A reading comprehension passage with some questions and writing about one of three writing topics. The final exam questions are stereotyped; writing about one topic of writing, answering a vocabulary exercise, answering an editing question, or a punctuation question.

Stereotyped EFL writing exams are another barrier to effective assessment in Egypt. Research pinpointed that stereotyped writing exams at the university level in Egypt need due attention as undergraduate students rely on these repetitive and stereotyped exams to succeed (Ahmed \& Myhill, 2016). This is true of the current study where teachers referred students to exams of previous years available in the library. Therefore, researchers recommend using valid and reliable formative and summative assessments that do not depend on memorisation or stereotyped exam questions (ibid).

The observers confirmed what students reported about stereotyped final exams.

In another lecturer, some students asked the teacher about the types of questions in the final exam, and the teacher said, "Look at copies available in the library, and the types of questions will be the same, but about different topics".

In addition, the three observed teachers referred to the final exams as students compete for the high marks during their university study:

The teacher told her students to study this exercise thoroughly because it is similar to the one in the final exam. Students were all ears when the teacher started talking about the final exam.

Data analysis indicated that students view their teachers as assessment illiterate, with authority and are afraid to be challenged. Teachers do not relay the assessment criteria or the marking scheme to students. For example, Asmaa, among three other students, said:

I do not even think that the teacher knows how to assess our writing. She did not tell us about her criteria for marking our written essays. All of us got excellent on our final exam although we are of different levels. Most of us 
completed the exam in half its time. I do not dare to say this to my teacher in class or privately as she could easily fail me in the course or take my university ID and dismiss me from attending her classes.

An important factor that most likely justifies some perspectives that L2 writing teachers hold relates to the issue of power relations. In this regard, Cummins (2009) pinpointed that the nature of the micro-interactions between teachers and their students is not neutral; they either enhance power relations or reinforce collaborative relations. Interview and observational data analysis reinforce what Cummins (2009) described as "...constrict the interpersonal space of classroom identity negotiation and contribute to the disempowerment of culturally-diverse students and communities" (p.263). This applies to the current study as we can argue that the Egyptian context seems to enhance strong power relations between students and teachers where it is scarce for students to argue, negotiate meaning or question teacher's authority (Ahmed, 2010a, p. 509; Ahmed, 2016).

\section{Assessment Criteria}

Findings of teachers' interviews indicated that six teachers confirmed that they often use some assessment criteria to mark students' essays. For example, Atiyat depended on general criteria to mark students' writing: good and relevant ideas, and clear English.

The criteria I use for marking students' writing are good ideas that are to the point and in good English. I do not give very high marks to students to be realistic about their level.

Similarly, Mostafa indicated in the following quotation that he assesses students' essays based on organisation, planning, mechanics, vocabulary and language.

In the final exam, I give some scores to the technical skills of writing, organisation, planning, mechanics, vocabulary and language.

When asked about her assessment criteria, Esraa referred to her use of assessment symbols to mark students' writing:

I use assessment symbols to help students understand their mistakes when they reread their work.

The above data shows that teachers' knowledge of assessment criteria is limited. In addition, it clear that teachers are not using any rubrics in their EFL writing assessment. The different foci of assessment criteria for different teachers indicate that they need training tailored to their needs to be assessment literate.

\subsection{Scoring Method}

Analysis of teachers' interviews and observation data showed that teachers follow the analytical scoring method. For example, Atiyat said:

I give 2 marks for content, 2 marks for punctuation (i.e. I give 1/4 a mark for each correct punctuation mark) and 2 marks for grammar and so on.

Analysis of observational data showed how teachers assess their students' writing:

A teacher informed students about how she scores their writing (2 marks for language use, 2 marks for mechanics, 4 marks for organisation and 2 marks for ideas).

In reference to the study participants, it is important to understand why students hold these views about assessment practices in the EFL writing. First, the Egyptian educational system stresses writing to pass exams which reduces EFL writing to a mere product and a grade (Ahmed \& Myhill, 2016). Second, teachers at a Faculty of Education lack assessment criteria (ibid). In addition, large class sizes of over 100 make it difficult for students to learn how to write and be assessed properly. As previously stated, students started to compete for fewer resources (Ahmed \& Myhill, 2016). Moreover, students' previous experiences with the assessment of writing at university made them very keen on getting the highest marks possible. Students held negative views towards assessment as their assessment experiences have been primarily high-stakes and exam-oriented. They might have obtained a bad grade in a previous writing course that made them only think of the exam and the final mark irrespective of learning experiences. Another issue that justifies their views might be employability after graduation, as the Ministry of Education in Egypt does not appoint teachers whose overall B.A. evaluation is less than "Merit". This intensifies the competition among students to survive in an environment where there are limited opportunities to succeed and work.

\section{IMPLICATIONS AND CONCLUSION}

Despite our small sample size, the findings of the current exploratory research are important to the field of EFL writing in general and to the Egyptian and similar EFL contexts in particular. The current research contributes to a better understanding of EFL writing assessment practices of in Egypt from teachers and students' perspectives. Using semi-structured interviews and observation as data collection tools add robustness and credibility to the findings of the study.

Based on the research findings and discussion, we propose some implications to enhance EFL writing assessment in Egypt. First, Colleges of Education need to recruit specialised and qualified EFL writing teachers to enhance students' learning/assessment experiences of EFL writing (Ahmed \& Myhill, 2016). Second, class sizes need to be fewer than 100 to effectively teach and assess students' EFL writing (Ahmed, 2016). In addition, EFL writing teachers need to be assigned reasonable teaching load that commensurates with their job ranks and experience to ensure the quality of teaching and assessment. This will have an impact on EFL writing assessment as teachers will have more time to mark students' writing and provide feedback to each student and more time for office hours where they can discuss their 
feedback with their students. Therefore, research recommends EFL writing lecturers in Egypt to combine oral and written feedback, give prompt feedback to students, and give critical and constructive feedback (Ahmed, 2010b, p.219).

Rewarding excellent teaching and reducing the power relations are two important considerations in EFL writing classes in Egypt. Departments and colleges need to reward teachers for their excellent teaching performance through financial incentives and promotion. These rewards encourage instructors to continue their journey of effective teaching. Furthermore, university regulations need to play an important role in reducing the culture of power relations of university teachers to help students learn in a positive learning environment where they negotiate and argue without fearing the authority of the teacher.

In reference to collegial interactions, it will be useful to organise some formal and informal meetings where teachers can exchange and disseminate knowledge and contribute positively to reform initiatives (Ingvarson, 1998; Mertler, 2009). These meetings will identify teachers' points of strength and areas for improvement in EFL writing assessment. Teachers need to become literate in diagnostic, formative, and summative assessment, rating scales, methods of scoring (i.e. analytical, holistic), self-assessment, peer assessment, and methods of marking students' writing (i.e. comprehensive vs selecting marking) (Ahmed, 2016).

In terms of resources and facilities, the university administration needs to exert all efforts to provide sufficient resources for both teachers and students to enrich the teaching and the learning experiences. This will minimise students' competition for learning and jobs. A follow-up plan should also be in place to ensure accountability among university teachers. Finally, a course syllabus, with clear EFL writing objectives, student learning outcomes and varied assessment tools, needs to be designed based on the latest trends in EFL writing assessment (Ahmed, 2011).

\section{APPENDIX (1). INTERVIEW SCHEDULE WITH EFL WRITING TEACHERS}

1. Is assessing students' writing important? Why?/Why not?

2. Do you use diagnostic assessment in your writing course? If yes, why?

3 . What formative assessments do you use in your writing course?

4. How do you view your formative assessments?

5. What summative assessments do you use and why?

6. How do you score your students' writing?

Probes: Holistic vs. analytical scoring?

7. Do you use a rubric to assess your students' writing?

Probes: - assessment criteria - a ready-made rubric or your own rubric? Why?

8. How do your students use the rubric?

9. How do you mark students' errors? Why?

Probes:

- Correct every single mistake (Comprehensive marking).

- Correct specific mistakes (Selective marking)

- Give comments - If yes, what type of comments do you give? Why?

\section{APPENDIX (2). INTERVIEW SCHEDULE WITH ENGLISH MAJORS}

1. Is your teacher's assessment of your written work useful? Why? Why not?

2. Does your teacher use diagnoses your writing skills before the start of the course?

3. Do you self-assess your writing? If yes, what do you think of it?

4. Do you review your classmates' writing? If yes, what do you think of this peer review process?

5. How does your teacher mark your writing?

a. A mark on your writing without comments.

b. A mark on your writing with comments.

6. Does your teacher use a rubric (assessment criteria) to assess your writing?

- What do you think of it?

7. Does your teacher give feedback on your writing? If yes, what do you think of it?

8. How does your teacher correct your errors in writing? Why?

Probes:

- Underline/circle the mistake

- Use self-correction symbols

- Add a question mark next to the error to self-correct

- Rewrite the sentence correctly

- Leave a comment.

ApPendix (3). Semi-STRuctured ObSERVATION SheEt

Year of Study: Teacher's Name:

Place of the Lecture: 
The objective of the Lecture:

Teaching/ Learning Materials:

\begin{tabular}{|l|l|l|l|}
\hline No. & Main Category & Descriptive Notes & Preliminary Analytic Notes \\
\hline 1. & Diagnostic assessment & & \\
\hline 2. & $\begin{array}{l}\text { Formative assessment } \\
\bullet \text { Self-assessment } \\
\bullet \text { Peer assessment } \\
\bullet \text { Teacher assessment }\end{array}$ & & \\
\hline 3. & Summative assessment & & \\
\hline 4. & Assessment criteria & & \\
\hline
\end{tabular}

\section{REFERENCES}

[1] Abouabdelkader, S. (2018). Moroccan EFL University Students' Composing Skills in the Balance: Assessment Procedures and Outcomes. In: Ahmed A., Abouabdelkader H. (Eds.) Assessing EFL Writing in the $21^{\text {st }}$ Century Arab World: Revealing the Unknown. Palgrave Macmillan, UK.

[2] Ahmed, (2011). The EFL/ESL Essay Writing Difficulties of Student Teachers of English: Implications for Curriculum Planning \& Design. An unpublished PhD Thesis, Graduate School of Education, University of Exeter, UK.

[3] Ahmed, A. \& Myhill, D. (2016). The impact of the socio-cultural context on L2 English writing of Egyptian university students. Learning, Culture \& Social Interaction, 11 (Pp. 117-129).

[4] Ahmed, A. (2010a). Contextual Challenges to Egyptian Students' Writing Development. The International Journal of Arts \& Sciences (IJAS), 1(4), (Pp.503-522).

[5] Ahmed, A. (2010b). Students' Problems with Cohesion and Coherence in EFL Essay Writing in Egypt: Different Perspectives. Literacy Information and Computer Education Journal (LICEJ), 1(4), Pp. 211-221.

[6] Ahmed, A. (2016). EFL Writing Instruction in an Egyptian University Classroom: An Emic View. Palgrave Macmillan Publications. In A. Ahmed \& H. Abouabdelkader (Eds.) Teaching EFL Writing in the $21^{\text {st }}$ Century Arab World: Realities \& Challenges. $1^{\text {st }}$ Edition, Palgrave Macmillan, UK.

[7] Ahmed, A. (2018). Assessment of EFL Writing in Some Arab University Contexts: Issues and Challenges. In A. Ahmed \& H. Abouabdelkader (Eds.). Assessing L2 Writing in the $21^{\text {st }}$ Century Arab World: Revealing the Unknown, $1^{\text {st }}$ Edition, Palgrave Macmillan, UK.

[8] Alderson, J. (2005). Diagnosing foreign language proficiency: the inter-face between learning and assessment. London: Continuum.

[9] Andrews, T. (2012). What is Social Constructionism? Grounded Theory Review, 11(1), p. 39.

[10] Assad, S. (1985). The Construction and Validation of a Multiple-Choice and a Performance Test of Communicative Writing Ability for the ESL Classroom. Dissertation Abstracts International, 45, 2880A.

[11] Athimni, M. (2018). Investigating Assessment Literacy in Tunisia: The Case of EFL University Writing Teachers. In: Ahmed A., Abouabdelkader H. (Eds.) Assessing EFL Writing in the $21^{\text {st }}$ Century Arab World: Revealing the Unknown. Palgrave Macmillan, UK.

[12] Baird. J. (2014). Teachers' views on assessment practices, Assessment in Education: Principles, Policy \& Practice, 21(4), 361364.

[13] Belachew, M., Getinet, M., Gashaye, A. (2015). Perception and practice of self-assessment in EFL writing classrooms. Journal of Languages and Culture. 6(1), pp. 1-8.

[14] BERA. (2004). Revisited Ethical Guidelines for Educational Purposes, British Educational Research Association, UK.

[15] Billington, H. (1997) Poster presentations and peer assessment: Novel forms of evaluation and assessment, Journal of Biological Education, 31 (3), pp. 218-220.

[16] Bostock, S. (2000). Student peer assessment. Available online at: http://www.ilt.ac.uk/1072.asp (accessed January 2016).

[17] Boyd, S., \& Wylie, C. (1994). Workload and Stress in New Zealand Universities. New Zealand Council for Educational Research, Wellington, New Zealand.

[18] Braine, G. (1996). ESL students in first-year writing courses: ESL versus mainstream classes. Journal of Second Language Writing, 5(2), 91-107.

[19] Brown, G. (1997). Assessing Student Learning in Higher Education. London: Routledge.

[20] Brown, S., Rust, C. and Gibbs, G. (1994). Involving students in the assessment process, in Strategies for Diversifying Assessments in Higher Education, Oxford: Oxford Centre for Staff Development, and at DeLiberations

[21] Brownell, S., \& Tanner, K. (2012). Barriers to faculty pedagogical change: Lack of training, time, incentives, and... tensions with professional identity. CBE-Life Sciences Education, 11(4), 339-346.

[22] Bryman, A. (2008). Social Research Strategies. Social Research Methods. (3 ${ }^{\text {rd }}$ ed.). New York: Oxford University Press.

[23] Burr, V. (1995). An introduction to social constructionism. London: Routledge.

[24] Cohen, L., Manion, L., \& Morrison, K. (2007). Research methods in education (6 $6^{\text {th }}$ ed.). Great Britain: Routledge.

[25] Crusan, D. (2010). Assess thyself lest others assess thee. In T. Silva, P. Matsuda (Eds.), Practicing Theory in Second Language Writing. West Lafayette, IN: Parlor Press.

[26] Crusan, D., Plakans, L., \& Gebril, A. (2016).Writing assessment literacy: Surveying second language teachers' knowledge, beliefs, and practices. Assessing Writing, 28. Pp. $43-56$.

[27] Cumming, A. (2004). Broadening, deepening, and consolidating. Language Assessment Quarterly, 1(1), 5-18.

[28] Cumming, A., \& So, S. (1996). Tutoring second language text revision: Does the approach to instruction or the language of communication make a difference? Journal of Second Language Writing, 5, 197-226. 
[29] Cummins, J. (2009). Pedagogies of choice: Challenging coercive relations of power in classrooms and communities. International Journal of Bilingual Education and Bilingualism, 12(3), 261-271.

[30] Davies, P. (2000) Computerized peer assessment. Innovations in Education and Training International, 37 (4), pp. $346-355$.

[31] Denzin, N., \& Lincoln, Y. (2000). Handbook of Qualitative Research (2nded.). London: Sage Publications, Thousand Oaks, New Delhi.

[32] Dornyei, Z. (2007). Research Methods in Applied Linguistics. Oxford: Oxford University Press.

[33] Faour, M. (2012). The Arab World's Education Report Card. School Climate and Citizenship Skills. Carnegie Middle East Center, Washington DC.

[34] Fareh, S. (2010). Challenges of teaching English in the Arab world: Why can't EFL programs deliver as expected? Procedia Social and Behavioural Sciences, 2. 3600-3604.

[35] Ferris, D., \& Roberts, B. (2001). Error feedback in L2 writing classes: How explicit does it need to be? Journal of Second Language Writing, 10(3), 161-184.

[36] Gebril, A., \& Brown, G. (2014). The effect of high-stakes examination systems on teacher beliefs: Egyptian teachers' conceptions of assessment. Assessment in Education: Principles, Policy \& Practice, 21(1), 16-33.

[37] Ghalib, T. (2018). EFL Writing Assessment and Evaluation Rubrics in Yemen. In: Ahmed A., Abouabdelkader H. (Eds.) Assessing EFL Writing in the $21^{\text {st }}$ Century Arab World: Revealing the Unknown. Palgrave Macmillan, UK.

[38] Given, L. (Ed.) (2008). The sage encyclopedia of qualitative research methods volumes 1 \& 2. London: Sage publication.

[39] Gore, J., Griffiths, T., \& Ladwig, J. (2004). Towards better teaching: Productive pedagogy as a framework for teacher education. Teaching and teacher education, 20(4), 375-387.

[40] Gorin, J. (2007). Test construction and diagnostic testing. In J. Leighton \& M. Gierl (Eds.), Cognitive diagnostic assessment for education: Theory and applications (pp. 173-201). New York: Cambridge University Press.

[41] Graham, S., Hebert, M., Harris, K. (2015). Formative Assessment and Writing: A Meta-Analysis. The Elementary School Journal, 115 (4), 207-241.

[42] Hailu, S., \& Rustaman, N. (2012). Final Exam report on first-semester Biology teaching and experience gained from Indonesia. Indonesia University of Education (UPI).

[43] Hargreaves, E. (2001). Assessment in Egypt. Assessment in Education: Principles, Policy \& Practice, 8:2, 247-260.

[44] Hartmann, S. (2008). The informal market of education in Egypt: Private tutoring and its implications. Institut für Ethnologie und Afrikastudien. Working Paper 88. Mainz, Germany: Johannes GutenbergUniversität.

[45] He, L., Shi, L. (2008). ESL students' perceptions and experiences of standardized English writing tests. Assessing Writing 13 (2008) 130-149.

[46] Henderson, C., Beach, A., Finkelstein, N. (2011). Facilitating change in undergraduate STEM instructional practices: an analytic review of the literature. Journal of Research in Science Teaching. 48, 952-984.

[47] Holliday, A. (2002). Doing and writing qualitative research. London: Sage publications.

[48] Hyde, B. (2002) Japan's emblematic English. English Today, 71 (18), p. 1216.

[49] Hyland, K. (2004). Assessing Student Writing. Second Language Writing. Cambridge: Cambridge University Press.

[50] Hyland, K. (2007). Genre pedagogy: Language, literacy and L2 writing instruction. Journal of Second Language Writing, 16(3), 148-164.

[51] Ingvarson, L. (1998). Professional development as the pursuit of professional standards: The standards-based professional development system. Teaching and Teacher Education, 14(1), 127-140.

[52] Jang, E. (2009). Cognitive diagnostic assessment of L2 reading comprehension ability: Validity arguments for Fusion Model application to LanguEdge assessment. Language Testing, 26(1), 031-73.

[53] Kasanen, K. \& Räty, H. (2002). "You be sure now to be honest in your assessment": Teaching and learning self-assessment. Social Psychology of Education, 5(4), 313-328.

[54] Klenowski, V. (1995). Student self-evaluation processes in student-centred teaching and learning contexts of Australia and England, Assessment in Education, 2, pp. 145-163.

[55] Lee, I. (2003). L2 writing teachers' perspectives, practices and problems regarding error feedback. Assessing Writing, 8, Pp. 216-237.

[56] Lee, I. (2011) Formative Assessment in EFL Writing: An Exploratory Case Study, Changing English, 18:1, 99-111.

[57] Leki, I., Cumming, A., \& Silva, T. (2008). A synthesis of research on second language writing in English. London: Routledge.

[58] Matsuda, P., Saenkhum, T., Accardi, S. (2013). Writing teachers' perceptions of the presence and needs of second language writers: An institutional case study. Journal of Second Language Writing, 22 68-86.

[59] Matsuno, S. (2009). Self-, peer-, and teacher-assessments in Japanese university EFL writing classrooms. Language Testing, 26(1), 75-100. doi: 10.1177/0265532208097337.

[60] Maxwell, J. (1996). Qualitative research design: An interactive approach. London: Sage Publications.

[61] McDonald, B. \& Boud, D. (2003). The impact of self-assessment on achievement: the effects of self-assessment training on performance in external examinations, Assessment in Education, 10(2), 209-220.

[62] Mertler, C. (2009). Teachers' assessment knowledge and their perceptions of the impact of classroom assessment professional development. Improving Schools, 12(2), 101-113.

[63] Miles, M., \& Huberman, A. (1994). Qualitative data analysis: An expanded sourcebook. Thousand Oaks, CA: Sage Publications.

[64] Mires, G., Ben- David, M., Preece, P., \& Smith, B. (2001). Educational benefits of student self- marking of short- answer questions. Medical Teacher, 23 (5), 462-466.

[65] Nelson, G., \& Carson, J. (1998). ESL students' perceptions of effectiveness in peer response groups. Journal of Second Language Writing, 7, 113-131.

[66] Nichols, P. (1994). A framework for developing cognitively diagnostic assessments. Review of Educational Research, 64(4), 575-603. 
[67] Orsmond, P., Merry, S., Reiling, K. (1997). A study in self- assessment: tutor and students' perceptions of performance criteria. Assessment and Evaluation in Higher Education, 22 (4), 357-369.

[68] Panadero, E., \& Romero, M. (2014). To rubric or not to rubric? The effects of self-assessment on self-regulation, performance and self-efficacy. Assessment in Education: Principles, Policy \& Practice, 21(2), Pp.133-148.

[69] Panadero, E., Brown, G. \& Courtney, M. (2014). Teachers' reasons for using self-assessment: a survey self-report of Spanish teachers, Assessment in Education: Principles, Policy \& Practice, 21:4, 365-383.

[70] Polio, C., \& Glew, M. (1996). ESL writing assessment prompts: How students choose. Journal of Second Language Writing, 5 (1), Pp. $35-49$.

[71] Pritchard, A., \& Woollard, J. (2010). Psychology for the classroom: Constructivism and social learning. London: Routledge.

[72] Race, P. (1998). Practical Pointers in Peer Assessment, in S. Brown, (Ed.) Peer Assessment in Practice, (SEDA paper 102) Birmingham: SEDA.

[73] Radnor, H. (2002). Researching Your Professional Practice. Open University Press, Buckingham.

[74] Ramdass, D., \& Zimmerman, B. J. (2008). Effects of self-correction strategy training on middle school students' self-efficacy, self-evaluation, and mathematics division learning. Journal of Advanced Academics, 20(1), 18-41. DOI: 10.4219/jaa-2008-869.

[75] Ramsden, P. (1992). Learning to Teach in Higher Education. London: Routledge.

[76] Ramsden, P. (1997). The context of learning in academic departments. In F. Marton, D., Hounsell, \& N. Entwistle (Eds.), The experience of learning. Implications for teaching and studying in higher education [second edition] (pp. 198-217). Edinburgh: Scottish Academic Press.

[77] Reichelt, M. (2009). A critical evaluation of writing teaching programmes in different foreign language settings. Writing in foreign language contexts: Learning, teaching, and research, Multilingual Matters, Pp. 183-206.

[78] Ruane, J. (2005). Watch and Learn: Field Research Essentials of Research Methods: A Guide to Social Science Research. Oxford: Blackwell Publishing.

[79] Sadek, N. (2018). The Effect of Self-Assessment as a Revision Technique on Egyptian EFL Students' Expository Essay Writing. In: Ahmed A., Abouabdelkader H. (Eds.) Assessing EFL Writing in the $21^{\text {st }}$ Century Arab World: Revealing the Unknown. Palgrave Macmillan, UK.

[80] Sadler, D. (1998). Formative assessment: revisiting the territory, Assessment in Education, 5(1), 77-84.

[81] Saito, H., \& Fujita, T. (2004). Characteristics and User Acceptance of Peer Rating in EFL Writing Classroom. Language Teaching Research, 8(1), 31-54, http://dx.doi.org/10.1191/13621688041r133oa.

[82] Sato, M., Wei, R., \& Darling-Hammond, L. (2008). Improving teachers' assessment practices through professional development: The case of National Board Certification. American Educational Research Journal, 45(3), 669-700.

[83] Seliem, S., \& Ahmed, A. (2009, March). Missing Electronic Feedback in Egyptian EFL Essay Writing Classes. Paper presented at the Centre for Developing English Language Teaching (CDELT) Conference, Cairo, Egypt. ERIC (ED505841).

[84] Shabana, N. (2018). Topical Structure Analysis: Assessing First-Year Egyptian University Students' Internal Coherence of Their EFL Writing. In: Ahmed A., Abouabdelkader H. (Eds.) Assessing EFL Writing in the $21^{\text {st }}$ Century Arab World: Revealing the Unknown. Palgrave Macmillan, UK.

[85] Silverman, D. (2001). Interpreting qualitative data: Methods for analysing talk, text and interaction. London: Sage Publications.

[86] Sluijsmans, D., Brand-Gruwel, S., \& Van Merriënboer, J. (2002). Peer assessment training in teacher education: Effects on performance and perceptions. Assessment \& Evaluation in Higher Education, 27(5), 443-454.

[87] Stiggins, R. (1995). Assessment literacy for the $21^{\text {st }}$ century. Phi Delta Kappan, 77(3), 238-45.

[88] Storch, N. (2009). The impact of studying in a second language (L2) medium university on the development of L2 writing. Journal of Second Language Writing, 18(2), 103-118.

[89] Taras, M. (2001). The use of tutor feedback and student self-assessment in summative assessment tasks; towards transparency for students and tutors, Assessment and Evaluation in Higher Education, 26(6), 605-614.

[90] Troudi, S., Coombe, C., and Al-Hamly, M. (2009). EFL Teachers' Views of English Language Assessment in Higher Education in the United Arab Emirates and Kuwait. TESOL Quarterly, Brief Reports, 43(3).

[91] Wang, W. (2014). Students' perceptions of rubric-referenced peer feedback on EFL writing: A longitudinal inquiry. Assessing Writing, 19 (2014) 80-96.

[92] Weber, A. (2018). English Writing Assessment and the Arabic Speaker: A Qualitative Longitudinal Retrospective on ArabicSpeaking Medical Students in Qatar. In: Ahmed A., Abouabdelkader H. (Eds.) Assessing EFL Writing in the $21^{\text {st }}$ Century Arab World: Revealing the Unknown. Palgrave Macmillan, UK.

[93] Weigle, S. (2012). Assessment of Writing. The Encyclopedia of Applied Linguistics. Cambridge, UK: Cambridge University Press.

[94] Winnaar, L.; Frempong, G.; Blignaut, R. (2011). Understanding school effects in South Africa using multilevel analysis: findings from TIMSS 2011. Electronic Journal of Research in Educational Psychology, 13(1), Pp. 151 - 170.

[95] Yang, T. (2007). Factors affecting EFL teachers' classroom assessment practices of young language learners. (PhD thesis, The University of Iowa, U.S.).

[96] Yuen, H. (1998). 'Implementing peer assessment and self-assessment in a Hong Kong classroom. Unpublished MA dissertation. The University of Hong Kong.

[97] Zariski, A. (1996). Student peer assessment in tertiary education: Promise, perils and practice. In Abbott, J. and Willcoxson, L. (Eds.), Teaching and Learning Within and Across Disciplines, p189-200. Proceedings of the $5^{\text {th }}$ Annual Teaching and Learning Forum, Murdoch University, February 1996. Perth: Murdoch University.

[98] Zhang, S. (1995). Reexamining the affective advantage of peer feedback in the ESL writing class. Journal of Second Language Writing, 4, 209-222. 


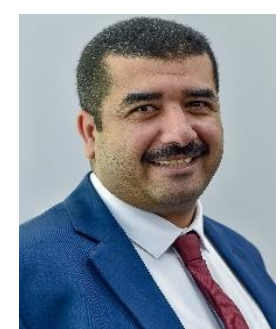

Abdelhamid M. Ahmed is Assistant Professor of Education (TESOL/Applied Linguistics), Curriculum \& Instruction Department, Faculty of Education, Helwan University, Egypt. He obtained his PhD in Education (TESOL/Applied Linguistics), Graduate School of Education, University of Exeter, UK. His areas of expertise include EFL writing problems, socio-cultural issues of EFL writing, academic writing, assessing writing, written feedback, and reflective journals. He is the co-editor of the following books: (1) Teaching EFL Writing in the $21^{\text {st }}$ Century Arab World: Realities \& Challenges, (2) Assessing EFL Writing in the $21^{\text {st }}$ Century Arab World: Revealing the Unknown, (3) The Handbook of General Education in MENA Higher Education. He also has some research publications in international peer-reviewed journals. He is experienced in teaching and researching EFL Writing as shown in his research publications. He is an editor in some journals and a research reviewer in others.

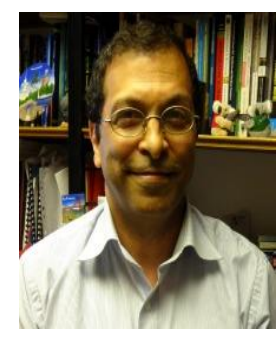

Salah Troudi is an academic at the Graduate School of Education of the University of Exeter where he is the director of the Doctorate in TESOL in Dubai and the supervisory coordinator of the PhD in TESOL. His teaching and research interests include language teacher education, critical issues in language education, language policy, curriculum development and evaluation, and classroom-based research. He has published articles in several language education journals and edited a number of books. 